\title{
Improved hydrogen desorption properties of Co-doped $\mathrm{Li}_{2} \mathrm{BNH}_{6}$
}

\author{
ZHENG XueLi1 ${ }^{1,2}$, WU GuoTao ${ }^{2 *}$, HE Teng ${ }^{2}$, CHU HaiLiang ${ }^{2}$, CHEN Hua ${ }^{1} \&$ CHEN Ping ${ }^{2}$ \\ ${ }^{1}$ Key Lab of Green Chemistry and Technology, Ministry of Education, the Institute of Homogeneous Catalysis, College of Chemistry, Sichuan \\ University, Chengdu 610064, China; \\ ${ }^{2}$ Dalian Institute of Chemical Physics, Chinese Academy of Sciences, Dalian 116023, China
}

Received August 13, 2010 ; accepted November 26, 2010

\begin{abstract}
The hydrogen desorption properties of $\mathrm{Li}_{2} \mathrm{BNH}_{6}$ were improved by doping with cobalt. With the addition of $\mathrm{CoCl}_{2}(7 \mathrm{wt} \%)$, more than $8 \mathrm{wt} \%$ of hydrogen was released from $\mathrm{Li}_{2} \mathrm{BNH}_{6}$ at temperatures below $210^{\circ} \mathrm{C}$, which is approximately $90^{\circ} \mathrm{C}$ lower than that of pristine $\mathrm{Li}_{2} \mathrm{BNH}_{6}$. X-ray diffraction, Fourier transform-infrared and Raman characterizations revealed that the dehydrogenation was a stepwise process with the formation of intermediates $\mathrm{Li}_{4} \mathrm{BN}_{3} \mathrm{H}_{10}$ and $\mathrm{LiBH}_{4}$ and final products of $\mathrm{Li}_{3} \mathrm{BN}_{2}$ and $\mathrm{LiH}$. The introduction of Co greatly accelerated the dehydrogenation of $\mathrm{Li}_{4} \mathrm{BN}_{3} \mathrm{H}_{10}$. X-ray absorption near-edge structure measurements revealed that $\mathrm{Co}$ and $\mathrm{CoB}$ species formed during ball milling of $\mathrm{CoCl}_{2}$ with $\mathrm{LiBH}_{4}$ and $\mathrm{LiNH}_{2}$, which may function as catalyst in the subsequent dehydrogenation.
\end{abstract}

lithium amide, cobalt, lithium borohydride, hydrogen release

Citation: Zheng X L, Wu G T, He T, et al. Improved hydrogen desorption properties of Co-doped $\mathrm{Li}_{2} \mathrm{BNH}_{6}$. Chinese Sci Bull, 2011, 56: 2481-2485, doi: $10.1007 / \mathrm{s} 11434-011-4466-3$

To meet the requirements for hydrogen fuel cell technology, tremendous efforts have been devoted to the development of hydrogen storage materials with high hydrogen contents [1]. Alanates [2], borohydrides [3], amide-hydride systems [4-7], ammonia borane [8,9], and metal amidoboranes $[10,11]$ have been explored as potential hydrogen storage materials. $\mathrm{LiBH}_{4}$ with a hydrogen capacity of $18.4 \mathrm{wt} \%$ [12], has attracted considerable research attention [3]. However, its thermal decomposition to $\mathrm{LiH}+\mathrm{B}+3 / 2 \mathrm{H}_{2}$ is a highly endothermic process (approximately $67 \mathrm{~kJ} \mathrm{~mol}^{-1} \mathrm{H}_{2}$ ) [13], and has a relatively high kinetic barrier [3], and thus requires high temperatures $\left(320-600^{\circ} \mathrm{C}\right)$ [3]. Several attempts to improve the thermodynamic properties of hydrogen release from $\mathrm{LiBH}_{4}$ have been made by reacting $\mathrm{LiBH}_{4}$ with chemicals such as $\mathrm{SiO}_{2}$ [3], $\mathrm{MgH}_{2}$ [13] and $\mathrm{CaH}_{2}$ [14]. Recent investigations revealed that complex hydrides $\left(\mathrm{LiAlH}_{4}\right.$, $\mathrm{LiBH}_{4}$ and $\mathrm{NaAlH}_{4}$ ) could be destabilized by reaction with alkali and alkali earth amides. It was reported that approximately $8.1 \mathrm{wt} \%$ of $\mathrm{H}_{2}$ can be released from $2 \mathrm{LiAlH}_{4}-\mathrm{LiNH}_{2}$

*Corresponding author (email: wgt@dicp.ac.cn) at $85-320^{\circ} \mathrm{C}$ [15]. Four equivalent of $\mathrm{H}_{2}$ were also found to evolve from $1 \mathrm{LiAlH}_{4}-2 \mathrm{LiNH}_{2}$ at $50-500^{\circ} \mathrm{C}$ [16]. Similar improvements were achieved by mixing $\mathrm{LiBH}_{4}$ with amides. Ball milling $\mathrm{LiBH}_{4}$ with 2 equivalent of $\mathrm{LiNH}_{2}$ produces $\mathrm{Li}_{3} \mathrm{BN}_{2} \mathrm{H}_{8}$, which can release $>10 \mathrm{wt} \%$ of $\mathrm{H}_{2}$ at $250-350^{\circ} \mathrm{C}$ [6,7]. In these hydride-amide systems where protic $\mathrm{H}$ and hydridic $\mathrm{H}$ coexist, the large potential for the combination of oppositely charged $\mathrm{H}$ atoms to form $\mathrm{H}_{2}$ and the establishment of a strong $\mathrm{B}-\mathrm{N}$ (or $\mathrm{Al}-\mathrm{N}$ ) bond should be the driving force for the favorable dehydrogenation. A series of quaternary complex hydrides, such as $\mathrm{Li}_{2} \mathrm{BNH}_{6}$, $\mathrm{Li}_{3} \mathrm{BN}_{2} \mathrm{H}_{8}$ and $\mathrm{Li}_{4} \mathrm{BN}_{3} \mathrm{H}_{10}$, can be prepared by mechanically milling $\mathrm{LiBH}_{4}$ and $\mathrm{LiNH}_{2}$ with various molar ratios [17]. However, those complex hydrides encounter very large kinetic barriers in dehydrogenation $[6,18]$. The $\mathrm{LiBH}_{4}-\mathrm{LiNH}_{2}$ system can be catalytically modified with transition metal additives, such as $\mathrm{PdCl}_{2}$, Pt/Vulcan carbon, $\mathrm{NiCl}_{2}, \mathrm{CoCl}_{2}$, can greatly reduce the dehydrogenation temperature [19-21]. In particular, $>9 \mathrm{wt} \%$ of $\mathrm{H}_{2}$ can be released from $\mathrm{Li}_{3} \mathrm{BN}_{2} \mathrm{H}_{8}$ at ca. $182^{\circ} \mathrm{C}$ in the presence of $5 \mathrm{wt} \%$ of Co-based catalyst [20]. Approximately $7.5 \mathrm{wt} \%$ of $\mathrm{H}_{2}$ was released from 
$\mathrm{Li}_{4} \mathrm{BN}_{3} \mathrm{H}_{10}$ at $160-260^{\circ} \mathrm{C}$ with the addition of $11 \mathrm{wt} \%$ of $\mathrm{NiCl}_{2}$ [21]. Co-based additives were also found to have a catalytic effect on the hydrogen release from boron-containing hydrogen storage materials [22,23]. The hydrogen capacity of $\mathrm{Li}_{2} \mathrm{BNH}_{6}\left(1 \mathrm{LiBH}_{4}-1 \mathrm{LiNH}_{2}\right)$ is $13.3 \mathrm{wt} \%$, which is higher than that in $\mathrm{Li}_{3} \mathrm{BN}_{2} \mathrm{H}_{8}(11.8 \mathrm{wt} \%)$ or $\mathrm{Li}_{4} \mathrm{BN}_{3} \mathrm{H}_{10}(11.0 \mathrm{wt} \%)$. However, there are few reports on the catalytic modification of this complex hydride. Herein, the dehydrogenations of pristine and the Co-doped $\mathrm{Li}_{2} \mathrm{BNH}_{6}$ are systematically investigated. It was found that the Co-additive promoted the dehydrogenation kinetics of $\mathrm{Li}_{2} \mathrm{BNH}_{6}$. The pathway of dehydrogenation was identified by X-ray diffraction (XRD), and Fourier transform-infrared (FT-IR) and Raman spectroscopy characterizations.

\section{Materials and methods}

$\mathrm{LiBH}_{4}(95 \%), \mathrm{LiNH}_{2}(95 \%)$ and anhydrous $\mathrm{CoCl}_{2}(97 \%)$ were purchased from Acros, Fluka and Sigma-Aldrich, respectively. To prevent oxygen and moisture contamination, all the sample loading and handling operations were conducted in an MBRAUN glovebox filled with purified argon.

A mixture of $\mathrm{LiBH}_{4}-\mathrm{LiNH}_{2}$ (molar ratio $1: 1$ ) was mechanically milled with $7 \mathrm{wt} \%$ of $\mathrm{CoCl}_{2}$ using a planetary Retch PM 400 mill. The ball-to-sample mass ratio was about 30:1. The rotation speed was regulated at $200 \mathrm{r} / \mathrm{min}$ and the milling time was $8 \mathrm{~h}$. At the end of ball milling the vessels were connected to a pressure gauge to measure the pressure inside. Then, the gaseous products were passed through a mass spectrometer (MS) for analysis. In contrast to the undoped $\mathrm{LiBH}_{4}-\mathrm{LiNH}_{2}$ sample, a small amount of $\mathrm{H}_{2}(0.07$ equivalent) was generated during ball milling.

A temperature-programmed desorption (TPD) system connected with a MS was constructed in our laboratory and used to investigate gas release. Approximately $50 \mathrm{mg}$ of sample was loaded and tested each time. The temperature was increased to $500^{\circ} \mathrm{C}$ at $2^{\circ} \mathrm{C} / \mathrm{min}$. The carrier gas was purified argon and the flow rate was set at $40 \mathrm{~mL} / \mathrm{min}$. Quantitative measurements on hydrogen release were performed on a commercial automatic Sieverts-type apparatus (Advanced Materials Co.). A sample of approximately 150 $\mathrm{mg}$ was tested with a heating rate of $2^{\circ} \mathrm{C} / \mathrm{min}$. The ammonia concentration in the gaseous product was measured by a Thermo conductivity meter with an accuracy of $0.1 \mu \mathrm{s} / \mathrm{cm}$. The $\mathrm{NH}_{3}$ concentration was proportional to the decrease in the ion conductivity measured after the outlet gas was passed through a dilute $\mathrm{H}_{2} \mathrm{SO}_{4}$ solution. A PANalytical $\mathrm{X}$ 'pert diffractometer equipped with $\mathrm{Cu} \mathrm{K} \alpha$ radiation (40 $\mathrm{kV}, 40 \mathrm{~mA}$ ) and an in situ cell was employed for structural identification. FT-IR measurements were conducted on a Varian 3100 FT-IR spectrometer. Raman spectra were recorded on a commercial micro-Raman spectrometer (Renishaw, UK) using a $\mathrm{He} / \mathrm{Ne}$ laser with a wavelength of $\lambda=$
$514 \mathrm{~nm}$. X-ray absorption near-edge structure (XANES) spectra were collected in fluorescence mode at the X-ray absorption fine structure (XAFS) station of the Shanghai Synchrotron Radiation Facility (SSRF, Shanghai). Samples for XAFS measurements were pressed into pellets in glovebox to avoid air contamination. Metallic cobalt foil and cobalt chloride were also measured as references and for energy calibration.

\section{Results and discussion}

\subsection{Hydrogen desorption from $\mathrm{Li}_{2} \mathrm{BNH}_{6}$}

$\mathrm{Li}_{2} \mathrm{BNH}_{6}$ can be prepared by mechanically milling $\mathrm{LiBH}_{4}$ and $\mathrm{LiNH}_{2}$ in a molar ratio of 1:1 [17]. In this study, formation of $\mathrm{Li}_{2} \mathrm{BNH}_{6}$ was observed by XRD in the pristine and Co-doped samples after $8 \mathrm{~h}$ of ball milling. The results of TPD measurements on the pristine and Co-doped $\mathrm{Li}_{2} \mathrm{BNH}_{6}$ samples are shown in Figure 1. For the pristine sample, hydrogen desorption began at approximately $170^{\circ} \mathrm{C}$ and peaked at $295^{\circ} \mathrm{C}$. The second step of desorption started at $370^{\circ} \mathrm{C}$ and reached the maximum desorption rate at around $410^{\circ} \mathrm{C}$. This dehydrogenation behavior is different from that of $\mathrm{Li}_{3} \mathrm{BN}_{2} \mathrm{H}_{8}$ and $\mathrm{Li}_{4} \mathrm{BN}_{3} \mathrm{H}_{10}$ [6,7,21]. By contrast, the Co-doped sample began to release hydrogen at approximately $110^{\circ} \mathrm{C}$, and reached the maximum desorption rate at approximately $230^{\circ} \mathrm{C}$, which is about $65^{\circ} \mathrm{C}$ lower than that of the pristine $\mathrm{Li}_{2} \mathrm{BNH}_{6}$. However, little improvement was observed in the second step of dehydrogenation. Quantitative measurements of hydrogen desorption from the pristine and Co-doped samples were conducted on a Sieverts-type apparatus. As shown in Figure 2, approximately 3.9 equivalent of $\mathrm{H}(8.6 \mathrm{wt} \%)$ was evolved from the pristine $\mathrm{Li}_{2} \mathrm{BNH}_{6}$ sample at $170-300^{\circ} \mathrm{C}$. In total, 5.3 equivalent of $\mathrm{H}(11.7 \mathrm{wt} \%)$ was desorbed when the temperature approached $450^{\circ} \mathrm{C}$. An acceleration of hydrogen release at about $290^{\circ} \mathrm{C}$ was observed, which was consistent with the TPD result. Nevertheless, it is clear that a large kinetic

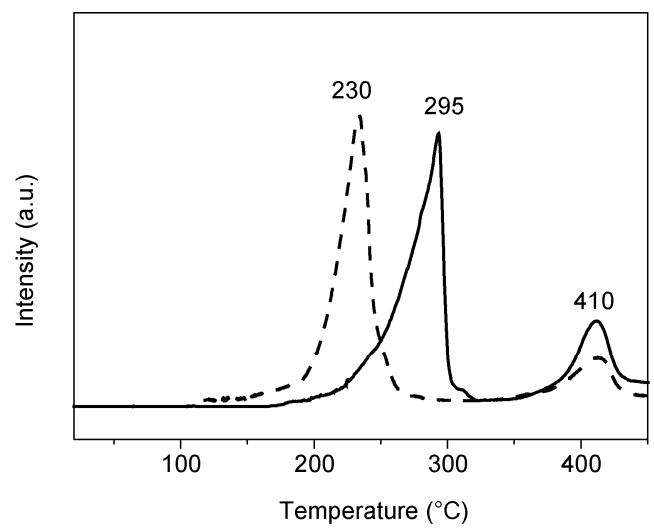

Figure 1 TPD-MS $\mathrm{H}_{2}$ spectra of pristine (solid line) and Co-doped $\mathrm{Li}_{2} \mathrm{BNH}_{6}$ samples (dotted line). 


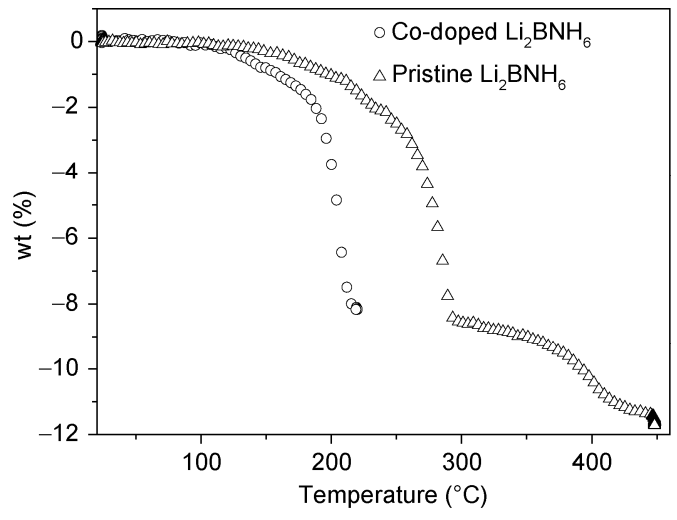

Figure 2 Volumetric release of hydrogen from pristine and Co-doped $\mathrm{Li}_{2} \mathrm{BNH}_{6}$ samples.

barrier resulted in hydrogen evolution occurring at higher temperatures. Introduction of $\mathrm{CoCl}_{2}$ into $\mathrm{Li}_{2} \mathrm{BNH}_{6}$ resulted in hydrogen evolution at approximately $110^{\circ} \mathrm{C}$ and acceleration of dehydrogenation was observed at around $200^{\circ} \mathrm{C}$. This is a major improvement compared with the pristine $\mathrm{Li}_{2} \mathrm{BNH}_{6}$. Approximately 3.9 equivalent of $\mathrm{H}(8.1 \mathrm{wt} \%)$ was desorbed in the first step at $<210^{\circ} \mathrm{C}$. The concentration of $\mathrm{NH}_{3}$ in the gaseous phase was below $890 \mathrm{ppm}$.

\subsection{Dehydrogenation mechanism}

As shown in Figure 1, dehydrogenation of $\mathrm{Li}_{2} \mathrm{BNH}_{6}$ is a two-step process. In order to gain insight into the reaction path, the Co-doped samples collected after ball milling and dehydrogenation at different stages were analyzed by XRD, FTIR, and Raman analyses. After $8 \mathrm{~h}$ of ball milling, the $\mathrm{LiBH}_{4}, \mathrm{LiNH}_{2}$ and $\mathrm{CoCl}_{2}$ reagents had disappeared and a new set of diffraction peaks attributed to $\mathrm{Li}_{2} \mathrm{BNH}_{6}$ was observed (Figure 3(b)) [17]. In the FTIR spectrum (Figure 4(b)) obtained after ball milling, peaks at 3293 and 3246 $\mathrm{cm}^{-1}$ were assigned to the symmetric and asymmetric $\mathrm{N}-\mathrm{H}$ stretching vibrations of $\mathrm{Li}_{2} \mathrm{BNH}_{6}$ [24]. The corresponding

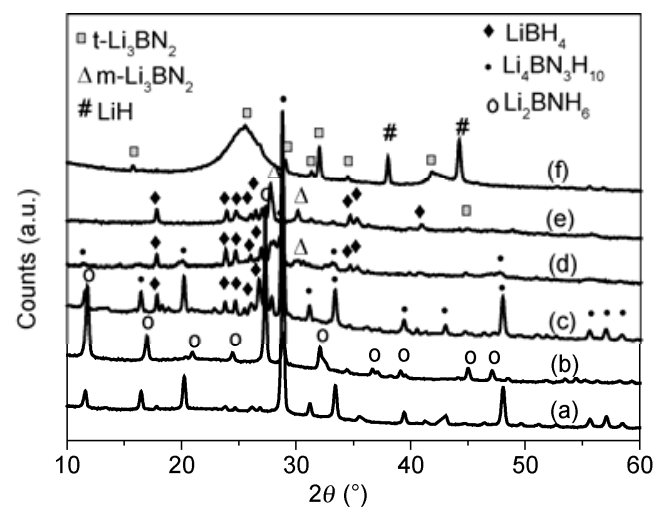

Figure 3 XRD patterns of (a) $\mathrm{Li}_{4} \mathrm{BN}_{3} \mathrm{H}_{10}$, (b) Co-doped $\mathrm{Li}_{2} \mathrm{BNH}_{6}$ after ball milling, and the samples collected after (c) heating at $90^{\circ} \mathrm{C}$, and release of (d) 2.2 , (e) 3.9 and (f) 5.3 equivalent of $\mathrm{H}$. t $-\mathrm{Li}_{3} \mathrm{BN}_{2}$ and $\mathrm{m}-\mathrm{Li}_{3} \mathrm{BN}_{2}$ reflect the tetragonal and monoclinic phases of $\mathrm{Li}_{3} \mathrm{BN}_{2}$, respectively.

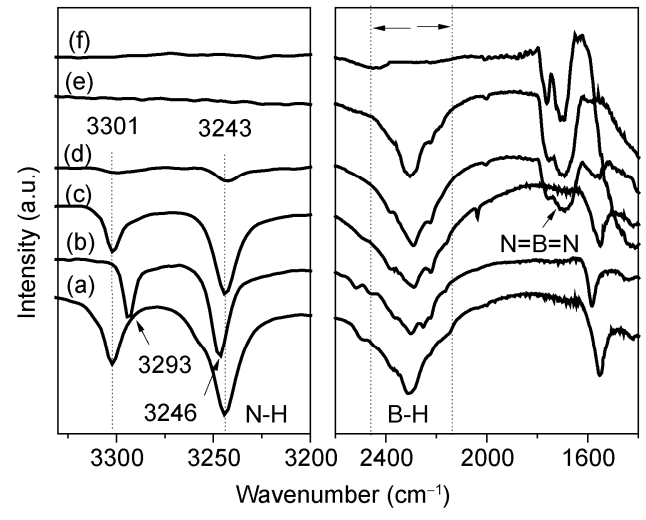

Figure 4 FTIR spectra of (a) $\mathrm{Li}_{4} \mathrm{BN}_{3} \mathrm{H}_{10}$, (b) Co-doped $\mathrm{Li}_{2} \mathrm{BNH}_{6}$ after ball milling, and the samples collected after (c) heating at $90^{\circ} \mathrm{C}$, and release of (d) 2.2 , (e) 3.9 and (f) 5.3 equivalent of $\mathrm{H}$.

Raman spectrum of $\mathrm{Li}_{2} \mathrm{BNH}_{6}$ (Figure 5(b)) also displayed peaks for the $\mathrm{N}-\mathrm{H}$ vibrations at $3296 \mathrm{~cm}^{-1}$ and $3247 \mathrm{~cm}^{-1}$, and the B-H vibrations at $2159 \mathrm{~cm}^{-1}$ (w), $2236 \mathrm{~cm}^{-1}$ (sh), $2296 \mathrm{~cm}^{-1}$ (s), and $2390 \mathrm{~cm}^{-1}$ (w). Upon heating the Co-doped $\mathrm{Li}_{2} \mathrm{BNH}_{6}$ sample at $90^{\circ} \mathrm{C}, \mathrm{Li}_{4} \mathrm{BN}_{3} \mathrm{H}_{10}$ and $\mathrm{LiBH}_{4}$ rather than $\mathrm{Li}_{2} \mathrm{BNH}_{6}$ were observed as the dominant phases by XRD (Figure 3(c)). FTIR spectrometry revealed that the peaks for the $\mathrm{N}-\mathrm{H}$ vibrations had shifted to $3301 \mathrm{~cm}^{-1}$ and $3243 \mathrm{~cm}^{-1}$ (Figure 4(c)). The intensities of the $\mathrm{N}-\mathrm{H}$ stretches decreased after approximately 2.2 equivalent of $\mathrm{H}$ was desorbed and a broad band centered at about $1680 \mathrm{~cm}^{-1}$ developed, which can be assigned to the vibration of $\mathrm{N}=\mathrm{B}=\mathrm{N}$ in $\mathrm{Li}_{3} \mathrm{BN}_{2}$ [25]. After releasing about 3.9 equivalent of $\mathrm{H}$ atoms at $<210^{\circ} \mathrm{C}$, the $\mathrm{N}-\mathrm{H}$ stretches disappeared and the broad band at $1680 \mathrm{~cm}^{-1}$ intensified.

After release of about 5.3 equiv. of $\mathrm{H}$ the $\mathrm{B}-\mathrm{H}$ stretches disappeared (Figure 4(f)). XRD characterization (Figure 3) indicated that the $\mathrm{Li}_{4} \mathrm{BN}_{3} \mathrm{H}_{10}$ phase was gradually weakened during dehydrogenation, and this was accompanied by a gradual increase of the monoclinic phase of $\mathrm{Li}_{3} \mathrm{BN}_{2}$ [26]. Finally, after the evolution of 5.3 equivalent of $\mathrm{H}$ at

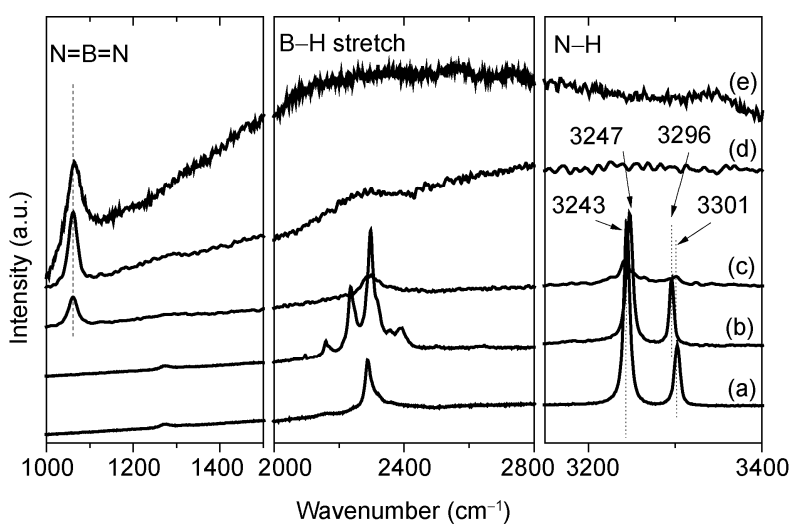

Figure 5 Raman spectra of (a) $\mathrm{Li}_{4} \mathrm{BN}_{3} \mathrm{H}_{10}$, (b) Co-doped $\mathrm{Li}_{2} \mathrm{BNH}_{6}$ after ball milling, and the samples collected after release of (c) 2.2, (d) 3.9 and (e) 5.3 equivalent of $\mathrm{H}$. 
$<450^{\circ} \mathrm{C}, \mathrm{LiBH}_{4}$ disappeared and $\mathrm{LiH}$ and tetragonal $\mathrm{Li}_{3} \mathrm{BN}_{2}$ appeared. In accordance with the XRD and FTIR characterizations, Raman spectra show the gradual decrease of the $\mathrm{N}-\mathrm{H}$ and $\mathrm{B}-\mathrm{H}$ vibrations, and the development of the $\mathrm{N}=\mathrm{B}=\mathrm{N}$ vibration in $\mathrm{Li}_{3} \mathrm{BN}_{2}\left(1060 \mathrm{~cm}^{-1}\right)$ (Figure 5) [27].

The pristine $\mathrm{Li}_{2} \mathrm{BNH}_{6}$ samples at different stages of dehydrogenation were also collected for structural characterization. The results showed an almost identical process with that of the Co-doped sample although the dehydrogenation occurred at much higher temperatures. This indicates that the main reaction pathway is unchanged by the introduction of $\mathrm{CoCl}_{2}$. Upon heating to approximately $90^{\circ} \mathrm{C}$, the conversion of $\mathrm{Li}_{2} \mathrm{BNH}_{6}$ to $\mathrm{Li}_{4} \mathrm{BN}_{3} \mathrm{H}_{10}$ and $\mathrm{LiBH}_{4}$ takes place (reaction (1) [28]. Hence, the decomposition of $\mathrm{Li}_{2} \mathrm{BNH}_{6}$ is likely to occur through dehydrogenation of $\mathrm{Li}_{4} \mathrm{BN}_{3} \mathrm{H}_{10}+1 / 2 \mathrm{LiBH}_{4}$ (reaction (2)) and then that of $\mathrm{LiBH}_{4}$ (reaction (3)). Therefore, the hydrogen release from the Co-doped and pristine $\mathrm{Li}_{2} \mathrm{BNH}_{6}$ can be expressed as follows:

$$
\begin{gathered}
\mathrm{Li}_{2} \mathrm{BNH}_{6} \rightarrow 1 / 3 \mathrm{Li}_{4} \mathrm{BN}_{3} \mathrm{H}_{10}+2 / 3 \mathrm{LiBH}_{4} \\
\mathrm{Li}_{4} \mathrm{BN}_{3} \mathrm{H}_{10}+1 / 2 \mathrm{LiBH}_{4} \rightarrow 3 / 2 \mathrm{Li}_{3} \mathrm{BN}_{2}+6 \mathrm{H}_{2} \\
\mathrm{LiBH}_{4} \leftrightarrow \mathrm{LiH}+3 / 2 \mathrm{H}_{2}+\mathrm{B}
\end{gathered}
$$

$\mathrm{Li}_{4} \mathrm{BN}_{3} \mathrm{H}_{10}$ releases hydrogen exothermically and its rehydrogenation is thermodynamically unfavorable [29]. Storage and release of hydrogen by $\mathrm{LiBH}_{4}$ is partially reversible [30]; therefore, the $\mathrm{Li}_{2} \mathrm{BNH}_{6}$ storage system may be partially reversible.

\subsection{Chemical state of Co catalyst}

After ball milling $\mathrm{LiBH}_{4}$ and $\mathrm{LiNH}_{2}$ with 7 wt\% of $\mathrm{CoCl}_{2}$ for $8 \mathrm{~h}, 0.07$ equiv alent of $\mathrm{H}_{2}$ was generated and the sample changed color from white to black. This indicates that the reduction of $\mathrm{CoCl}_{2}$ occurred during the milling process. However, no Co-related phases were observed in the XRD pattern, which is probably due to the low loading and/or poor crystallinity. More information regarding the chemical state and local environment of Co were obtained from the XAFS analyses. The XANES of the freshly ball-milled sample resembled that of metallic Co (Figure 6), which indicates that reduction of $\mathrm{CoCl}_{2}$ by $\mathrm{LiBH}_{4}$ occurred during ball-milling. Fourier transformation of the XAFS spectra showed that the ball milled sample had a dominant peak at around $2.53 \AA$ with a shoulder at $1.94 \AA$ (Figure 7), which are close to the second shell Co-Co distance $(2.67 \AA)$ and the first shell Co-B distance (2.08 $\AA$ ) of $\mathrm{CoB}$, respectively [31]. As Tang et al. [20] revealed, both $\mathrm{Co}$ and $\mathrm{CoB}$ species have catalytic effects on the dehydrogenation of $\mathrm{Li}_{3} \mathrm{BN}_{2} \mathrm{H}_{8}$. Similarly, in the present case, Co and $\mathrm{CoB}$ species might also co-function as the catalyst. Co particles might have poor crystallinity and are finely dispersed in the sample, which leads to a high catalytic efficiency. It is likely that the Co particles could facilitate the formation of $\mathrm{Li}_{3} \mathrm{BN}_{2}$, and consequently decrease the dehydrogenation temperature and

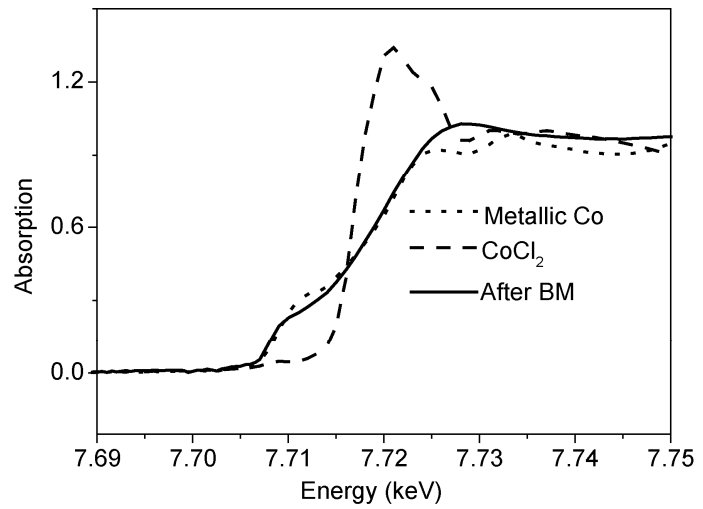

Figure 6 Co K-edge XAFS spectra of metallic $\mathrm{Co}, \mathrm{CoCl}_{2}$ and post-milled Co-doped $\mathrm{Li}_{2} \mathrm{BNH}_{6}$.

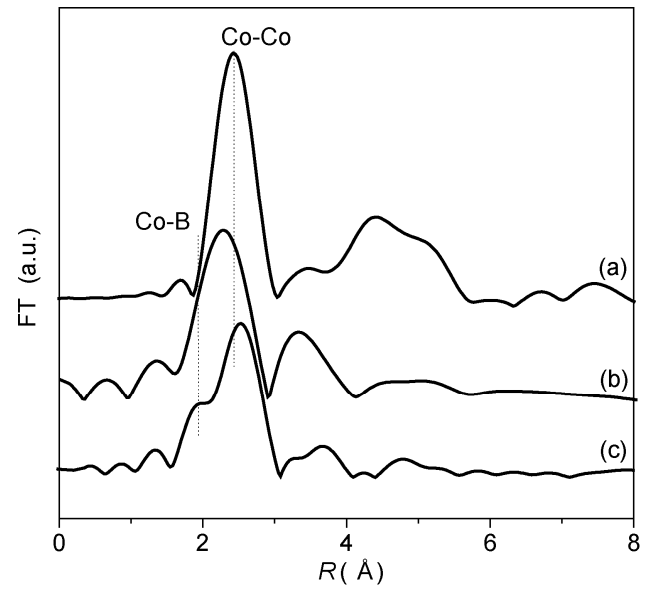

Figure 7 Fourier transformed spectra of (a) metallic $\mathrm{Co}$, (b) $\mathrm{CoCl}_{2}$ and (c) post-milled Co-doped $\mathrm{Li}_{2} \mathrm{BNH}_{6}$.

improve the dehydrogenation kinetics, as well as in the Co-doped dehydrogenation of $\mathrm{NH}_{3} \mathrm{BH}_{3}$ and $\mathrm{Li}_{3} \mathrm{BN}_{2} \mathrm{H}_{8}$ $[32,33]$.

\section{Conclusion}

$\mathrm{Li}_{2} \mathrm{BNH}_{6}$ undergoes a stepwise dehydrogenation with initial transformation into $\mathrm{Li}_{4} \mathrm{BN}_{3} \mathrm{H}_{10}$ and $\mathrm{LiBH}_{4}$ at about $90^{\circ} \mathrm{C}$. Subsequent decomposition to $\mathrm{Li}_{3} \mathrm{BN}_{2}$ and $\mathrm{H}_{2}$ occurs at around $300^{\circ} \mathrm{C}$, and final full dehydrogenation to $\mathrm{LiH}, \mathrm{B}$ and $\mathrm{Li}_{3} \mathrm{BN}_{2}$ occurs at $450^{\circ} \mathrm{C}$. The addition of $\mathrm{CoCl}_{2}$ (7 wt $\%$ ) to $\mathrm{Li}_{2} \mathrm{BNH}_{6}$ greatly reduced the hydrogen desorption temperature. More than $8 \mathrm{wt} \%$ of hydrogen can be released at $<210^{\circ} \mathrm{C}$. XANES measurements revealed that $\mathrm{Co}$ and $\mathrm{CoB}$ were formed after ball milling of $\mathrm{CoCl}_{2}$ with $\mathrm{LiNH}_{2}$ and $\mathrm{LiBH}_{4}$.

This work was supported by the Hundred Talents Project of Chinese Academy of Sciences (KGCX2-YW-806), the Knowledge Innovation Program of Chinese Academy of Sciences (KJCX2-YW-H21), the National Hi-Tech Research \& Development Project of China (2009AA05Z108), the 
National Natural Science Foundation of China (10979051, 20971120, 20973162). The authors thank the Shanghai Synchrotron Radiation Facility for providing time on beamline BL14W1.

1 Schlapbach L, Züttel A. Hydrogen-storage materials for mobile applications. Nature, 2001, 414: 353-358

2 Bogdanović B, Schwickardi M. Ti-doped alkali metal aluminium hydrides as potential novel reversible hydrogen storage materials. J Alloys Compd, 1997, 253: 1-9

3 Züttel A, Wenger $\mathrm{P}$, Rentsch $\mathrm{S}$, et al. $\mathrm{LiBH}_{4}-\mathrm{A}$ new hydrogen storage material. J Power Sources, 2003, 118: 1-7

4 Chen P, Xiong Z T, Luo J Z, et al. Interaction of hydrogen with metal nitrides and imides. Nature, 2002, 420: 302-304

5 Leng $\mathrm{H} \mathrm{Y}$, Ichikawa $\mathrm{T}$, Hino $\mathrm{S}$, et al. New metal-N-H system composed of $\mathrm{Mg}\left(\mathrm{NH}_{2}\right)_{2}$ and $\mathrm{LiH}$ for hydrogen storage. J Phys Chem B, 2004, 108: 8763-8765

6 Pinkerton F E, Meisner G P, Meyer M S, et al. Hydrogen desorption exceeding ten weight percent from the new quaternary hydride $\mathrm{Li}_{3} \mathrm{BN}_{2} \mathrm{H}_{8}$. J Phys Chem B, 2005, 109: 6-8

7 Aoki M, Miwa K, Noritake T, et al. Destabilization of $\mathrm{LiBH}_{4}$ by mixing with $\mathrm{LiNH}_{2}$. Appl Phys A: Mater Sci Proc, 2005, 80: 1409-1412

8 Wolf G, Baumann J, Baitalow F, et al. Calorimetric process monitoring of thermal decomposition of B-N-H compounds. Thermochim Acta, 2000, 343: 19-25

9 Gutowska A, Li L Y, Shin Y S, et al. Nanoscaffold mediates hydrogen release and the reactivity of ammonia borane. Angew Chem Int Ed, 2005, 44: 3578-3582

10 Xiong Z T, Yong C K, Wu G T, et al. High-capacity hydrogen storage in lithium and sodium amidoboranes. Nat Mater, 2008, 7: 138-141

11 Diyabalanage H V K, Shrestha R P, Semelsberger T A, et al. Calcium amidotrihydroborate: A hydrogen storage material. Angew Chem Int Ed, 2007, 46: 8995-8997

12 Schlesinger H I, Brown H C. Metallo borohydrides. III. Lithium borohydride. J Am Chem Soc, 1940, 62: 3429-3435

13 Vajo J J, Skeith S L, Mertens F. Reversible storage of hydrogen in destabilized LiBH. J Phys Chem B, 2005, 109: 3719-3722

14 Yang J, Sudik A, Wolverton C. Destabilizing $\mathrm{LiBH}_{4}$ with a metal (M $=\mathrm{Mg}, \mathrm{Al}, \mathrm{Ti}, \mathrm{V}, \mathrm{Cr}$, or Sc) or metal hydride $\left(\mathrm{MH}_{2}, \mathrm{MgH}_{2}, \mathrm{TiH}_{2}\right.$, or $\mathrm{CaH}_{2}$ ). J Phys Chem C, 2007, 111: 19134-19140

15 Lu J, Fang Z G Z. Dehydrogenation of a combined $\mathrm{LiAlH}_{4} / \mathrm{LiNH}_{2}$ system. J Phys Chem B, 2005, 109: 20830-20834

16 Xiong Z T, Wu G T, Hu J J, et al. Reversible hydrogen storage by a Li-Al-N-H complex. Adv Funct Mater, 2007, 17: 1137-1142

17 Meisner G P, Scullin M L, Balogh M P, et al. Hydrogen release from mixtures of lithium borohydride and lithium amide: A phase diagram study. J Phys Chem B, 2006, 110: 4186-4192

18 Noritake T, Aoki M, Towata S, et al. Crystal structure analysis of novel complex hydrides formed by the combination of $\mathrm{LiBH}_{4}$ and $\mathrm{LiNH}_{2}$. Appl Phys A: Mater Sci Proc, 2006, 83: 277-279

19 Pinkerton F E, Meyer M S, Meisner G P, et al. Improved hydrogen release from $\mathrm{LiB}_{0.33} \mathrm{~N}_{0.67} \mathrm{H}_{2.67}$ with metal additives: $\mathrm{Ni}, \mathrm{Fe}$, and $\mathrm{Zn}$. J Alloys Compd, 2007, 433: 282-291

20 Tang W S, Wu G, Liu T, et al. Cobalt-catalyzed hydrogen desorption from the $\mathrm{LiNH}_{2}-\mathrm{LiBH}_{4}$ system. Dalton Trans, 2008: 2395-2399

21 Pinkerton F E, Meyer M S. Hydrogen desorption behavior of nickel-chloride-catalyzed stoichiometric $\mathrm{Li}_{4} \mathrm{BN}_{3} \mathrm{H}_{10}$. J Phys Chem C, 2009, 113: 11172-11176

22 He T, Xiong Z T, Wu G T, et al. Nanosized Co- and Ni-catalyzed ammonia borane for hydrogen storage. Chem Mater, 2009, 21: 2315-2318

23 Chu H L, Xiong Z T, Wu G T, et al. Hydrogen storage properties of $\mathrm{Ca}\left(\mathrm{BH}_{4}\right)_{2}-\mathrm{LiNH}_{2}$ system. Chem Asian J, 2010, 5: 1594-1599

24 Chater P A, David W I F, Johnson S R, et al. Synthesis and crystal structure of $\mathrm{Li}_{4} \mathrm{BH}_{4}\left(\mathrm{NH}_{2}\right)_{3}$. Chem Commun, 2006: 2439-2441

25 Kulinich S A, Zhukov A N, Sevast'yanova L G, et al. On some alkaliand alkaline-earth-metal boron nitrides, unsaturated with boron. Diam Relat Mater, 1999, 8: 2152-2158

26 Yamane H, Kikkawa S, Horiuchi H, et al. Structure of a new polymorph of lithium boron nitride, $\mathrm{Li}_{3} \mathrm{BN}_{2}$. J Solid State Chem, 1986, 65: 6-12

27 Somer M, Herterich U, Curda J, et al. Ternary nitridoborates. 1. $\mathrm{LiMg}\left[\mathrm{BN}_{2}\right]$ and $\mathrm{Ba}_{4}\left[\mathrm{BN}_{2}\right]_{2} \mathrm{O}$, compounds with the anion $[\mathrm{N}-\mathrm{B}-\mathrm{N}]^{3-}$ : Syntheses, crystal structures, and vibrational spectra. Z Anorg Allg Chem, 1997, 623: 18-24

28 Chater P A, David W I F, Anderson P A. Synthesis and structure of the new complex hydride $\mathrm{Li}_{2} \mathrm{BH}_{4} \mathrm{NH}_{2}$. Chem Commun, 2007: 47704772

29 Pinkerton F E, Meyer M S, Meisner G P, et al. Improved hydrogen release from $\mathrm{LiB}_{0.33} \mathrm{~N}_{0.67} \mathrm{H}_{2.67}$ with noble metal additions. $\mathrm{J}$ Phys Chem B, 2006, 110: 7967-7974

30 Orimo S, Nakamori Y, Kitahara G, et al. Dehydriding and rehydriding reactions of $\mathrm{LiBH}_{4}$. J Alloys Compd, 2005, 404-406: 427-430

31 Pei Y, Guo P J, Qiao M H, et al. The modification effect of Fe on amorphous $\mathrm{CoB}$ alloy catalyst for chemoselective hydrogenation of crotonaldehyde. J Catal, 2007, 248: 303-310

$32 \mathrm{Xu}$ Q, Chandra M. Catalytic activities of non-noble metals for hydrogen generation from aqueous ammonia-borane at room temperature. J Power Sources, 2006, 163: 364-370

33 Liu Y F, Luo K, Zhou Y F, et al. Diffusion controlled hydrogen desorption reaction for the $\mathrm{LiBH}_{4} / 2 \mathrm{LiNH}_{2}$ system. J Alloys Compd, 2009, 481: 473-479

Open Access This article is distributed under the terms of the Creative Commons Attribution License which permits any use, distribution, and reproduction in any medium, provided the original author(s) and source are credited. 